\title{
Oil, Protein, Chlorophyll, Cadmium and Lead Contents of Seeds in Oil and Fiber Flax (Linum usitatissimum L.) Cultivars and in Oil Hemp (Cannabis sativa L.) Cultivar Finola Cultivated in South-Western Part of Finland
}

\author{
Marketta Saastamoinen $^{1^{*}}$, Merja Eurola $^{2}$ and Veli Hietaniemi ${ }^{3}$ \\ ${ }^{1}$ Satafood Development Association, Viialankatu 25, FI-32700 Huittinen, Finland \\ ${ }^{2}$ Merja Eurola, Natural Resources Institute Finland, Management and Production of Renewable Resources, FI-31600 Jokioinen, Finland \\ ${ }^{3}$ Natural Resources Institute Finland, Bio-based business and industry, FI-31600 Jokioinen, Finland
}

"Correspondence to:

Marketta Saastamoinen

Satafood Development Association

Viialankatu 25, FI-32700 Huittinen, Finland

E-mail: marke.saastamoinen@gmail.com

Received: February 03, 2016

Accepted: April 06, 2016

Published: April 08, 2016

Citation: Saastamoinen M, Eurola M, Hietaniemi V. 2016. Oil, Protein, Chlorophyll, Cadmium and Lead Contents of Seeds in Oil and Fiber Flax (Linum usitatissimum L.) Cultivars and in Oil Hemp (Cannabis sativa L.) Cultivar Finola Cultivated in South-Western Part of Finland. $J$ Food Chem Nanotechnol 2(2): 73-76.

Copyright: (c) 2016 Saastamoinen et al. This is an Open Access article distributed under the terms of the Creative Commons Attribution 4.0 International License (CC-BY) (http:// creativecommons.org/licenses/by/4.0/) which permits commercial use, including reproduction, adaptation, and distribution of the article provided the original author and source are credited.

Published by United Scientific Group

\begin{abstract}
Chemical composition of seeds of two minor oil crops, flax (Linum usitatissimum L.) and oil hemp (Cannabis sativa L.) cultivated in Finland were analyzed and compared to others. Oilseed flax cultivars were Abacus, Aries, Comtess, Heljä, Helmi, Laser, Sunrise, and Taurus, three fiber flax cultivars were Belinka, Martta and Snaigiai. Oil hemp cultivar was Finola, a Finnish cultivar with low cannabinoids content. Oil content was higher in oil flax cultivars (42.2-48.8 mg $\left.100 \mathrm{~g}^{-1}\right)$ than in fiber flax (34.8-42.2 mg $\left.100 \mathrm{~g} \mathrm{~g}^{-1}\right)$ and oil hemp (34.6 mg $100 \mathrm{~g}^{-1}$ ) cultivars. Protein contents were lower in high oil flax cultivars than in fiber flax cultivars. Very great difference between the species was in chlorophyll content, which was much higher in oil hemp $\left(138.3 \mathrm{mg} \mathrm{kg}^{-1}\right)$ than in oilseed $\left(0-6.8 \mathrm{mg} \mathrm{kg}^{-1}\right)$ or fiber flax (5.9-11.0 $\left.\mathrm{mg} \mathrm{kg}^{-1}\right)$ cultivars. Oil hemp is so late in Finland that all seeds do not ripen well. Cadmium contents of oilseed (0.390-0.797 mg kg-1) and fiber flax (0.497-0.600 mg kg-1) cultivars were much higher than those of oil hemp $\left(0.020 \mathrm{mg} \mathrm{kg}^{-1}\right)$. Oil hemp cultivar Finola did not accumulate cadmium from the soil. Lead contents were low.
\end{abstract}

\section{Keywords}

Oil, Protein, Chlorophyll content, Cadmium, Lead, Flax, Oil hemp

\section{Introduction}

Flax (Linum usitatissimum L.) and hemp (Cannabis sativa L.) are very variable plants. Flax and hemp are food and feed plants, which produce both food or feed and fiber. Flax oil can be used as technical purposes, too, e.g. in production of oil colors, and linoleum floors. Both plant species include fiber and oil cultivars, those yield is used as food or feed. Cannabis sativa L. includes oil cultivars, which have very low content of cannabinoids. Eighty five different cannabinoids have been found from Cannabis sativa [1]. The psychoactive cannabinoid is tetrahydrocannabinol (THC) ((6aR, 10aR)-delta-9-tetrahydrocannabinol) $[2,3]$. Its content in yield of hemp must not exceed $0.2 \%\left(2 \mathrm{mg} \mathrm{kg}^{-1}\right)$ in $\mathrm{EU}$ countries [4]. There are no common limits for different food and feed products in EU countries, but they are differing in different countries.

Oilseed flax and oil hemp are currently cultivated in Finland. Oilseed flax and oil hemp are minor oil crops in Finland. Oilseed flax is cultivated 1000-2000 ha yearly, and oil hemp even less. The average yield of oilseed flax in Finland is about 1000 $\mathrm{kg} \mathrm{ha}^{-1}$. The seed yield of oil hemp is about 700-1000 kg ha-1 in Finland. There is one oil hemp cultivar, Finola with low THC content in Finland. The production of fiber flax and hemp cultivars is small as the textile industry is uneconomical and fiber production must compete with forest fiber production. Cellulose nanofiber 
is prepared by chemical treatments and separation techniques from flax and hemp composites [5].

Oilseed flax and hemp oil are used as food and feed as special purposes for their beneficial effects on health. They contain high linoleic and linolenic acid contents. Linolenic acid content of oilseed flax oil is higher, 53\% [6], than that of hempseed oil [7]. Hempseed oil contains also gammalinolenic acid 4\% in the oil [8]. The yield of gamma linolenic acid has been 3-30 kg ha-1 for different genotypes of oil hemp being at the same level as in borage (Borago officinalis L.) (19$30 \mathrm{~kg} \mathrm{ha}^{-1}$ ) and evening primrose (Oenothera biennis L. Scop.) $\left(7-30 \mathrm{~kg} \mathrm{ha}^{-1}\right)$ [9], which are cultivated for gamma linolenic acid. Hempseed oil has been as effective as oilseed flax oil in lowering serum cholesterol [10]. It has been found, that conjugated linoleic acid content of cow milk is increased by a diet containing 2.2 and $4.4 \%$ flax oil [11]. Protein content and quality of oilseed flax and oil hemp are good. Seed chemical quality of oilseed flax and oil hemp is good, but both species are able to accumulate cadmium from the soil $[12,13]$.

\section{Material and Methods}

Material consisted of farm and trial seed samples of oilseed and fiber flax as described previously [14] added by two flax trials from the year 2011 and farm samples oil hemp from the same area of south-western part of Finland from the years 2005 and 2007-11. Oil hemp samples were Finola cultivar which is the only oil hemp cultivar cultivated in Finland. Oil, protein, cadmium and lead contents were analyzed as described previously [14]. Chlorophyll contents were analyzed according the official methods used in Finland [15]. Dried and cooled seeds ( $5 \mathrm{~g}$ ) are weighed to metal tubes and crushed and dissolved in a mixture of gasoline 80/100 $(750 \mathrm{~mL})$ and absolute ethanol $(250 \mathrm{~mL}) 50 \mathrm{~min}$ by 200 per min, centrifuged $10 \mathrm{~min} 3000 \mathrm{r}$ per min. Supernatant is measured by spectrophotometer beginning at $655 \mathrm{~nm}$, searching the maximum wave length. If the absorbance (A) at $670 \mathrm{~nm}$ is over 0.7 , supernatant is diluted to $1.75 \mathrm{~mL}$ dilution mixture. Dilution is taken into consideration in calculation. Chlorophyll content in oil $\left(\mathrm{mg} \mathrm{kg}^{-1}\right)$ is calculated by the following equations:

- $A_{\text {diff }}=\left(A_{667 \mathrm{~nm}}-\left(\mathrm{A}_{627 \mathrm{~nm}}+\mathrm{A}_{707 \mathrm{~nm}}\right)\right) / 2$.

- Chlorophyll, $\mathrm{mg} \mathrm{kg}{ }^{-1}=\left(\mathrm{A}_{\text {diff }} \times 0.933 \times 15\right) /(0.1016 \times 1 \times \mathrm{g})$,

Statistical analyses were calculated by Statistica program.

\section{Results and Discussion}

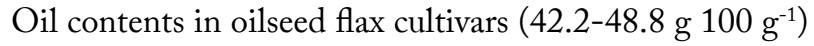
were higher than those in fiber flax cultivars $\left(34.8-42.2{\left.\mathrm{~g} 100 \mathrm{~g}^{-1}\right)}^{-1}\right.$ (Table 1) and in oil hemp cultivar Finola (34.6 g $100 \mathrm{~g}^{-1}$ ) (Table 2). Oilseed and fiber flax cultivars differed significantly in their oil contents. Callaway [8] has reported $35.5 \%$ oil content in Finola oil hemp. Bayrak et al. [16] have reported 23.3-40.4\% oil content in Linum usitatissimum genotypes. Finola hemp seed oil contains palmitic (6.0\%), stearic (2.4\%), oleic (8.6\%), linoleic (54.2\%), alpha-linolenic acid (21.7\%) and also $3.9 \%$ of gamma-linolenic and $1.9 \%$ stearidonic acid

Table 1: Oil, protein, chlorophyll, cadmium and lead contents from dry matter of seeds of oil and fiber flax cultivars in 2007-11.

\begin{tabular}{|c|c|c|c|c|c|c|c|c|c|c|c|c|c|}
\hline \multirow[t]{2}{*}{$\begin{array}{l}\text { Type of } \\
\text { variety }\end{array}$} & \multirow[t]{2}{*}{ Cultivar } & \multirow{2}{*}{$\begin{array}{c}\text { Number } \\
\text { of samples }\end{array}$} & \multicolumn{2}{|c|}{$\begin{array}{l}\text { Oil content } \\
\left(\mathrm{g} 100 \mathrm{~g}^{-1}\right)\end{array}$} & \multicolumn{2}{|c|}{$\begin{array}{l}\text { Protein content } \\
\qquad\left(\mathrm{g} 100 \mathrm{~g}^{-1}\right)\end{array}$} & \multicolumn{2}{|c|}{$\begin{array}{l}\text { Chlorophyll content } \\
\left(\mathrm{mg} \mathrm{kg}^{-1}\right)\end{array}$} & \multirow{2}{*}{$\begin{array}{c}\begin{array}{c}\text { Number } \\
\text { of samples }\end{array} \\
\mathrm{n}\end{array}$} & \multicolumn{2}{|c|}{$\begin{array}{c}\text { Cadmium content }{ }^{1} \\
\left(\mathrm{mg} \mathrm{kg}^{-1}\right)\end{array}$} & \multicolumn{2}{|c|}{$\begin{array}{l}\text { Lead content }^{1} \\
\left(\mathrm{mg} \mathrm{kg}^{-1}\right)\end{array}$} \\
\hline & & & Mean & $\begin{array}{l}\text { Std. } \\
\text { Dev. }\end{array}$ & Mean & $\begin{array}{l}\text { Std. } \\
\text { Dev. }\end{array}$ & Mean & Std. Dev. & & Mean & $\begin{array}{l}\text { Std. } \\
\text { Dev. }\end{array}$ & Mean & $\begin{array}{l}\text { Std. } \\
\text { Dev }\end{array}$ \\
\hline \multirow[t]{7}{*}{ Oil } & Helmi & 10 & 42.2 & 1.66 & 23.8 & 2.15 & 2.92 & 2.40 & 9 & 0.797 & 0.42 & 0.031 & 0.02 \\
\hline & Heljä & 5 & 44.2 & 3.16 & 24.1 & 2.91 & 2.06 & 1.42 & 3 & 0.523 & 0.08 & 0.012 & 0.01 \\
\hline & Taurus & 4 & 44.6 & 6.81 & 23.1 & 1.90 & 5.05 & 3.41 & 2 & 0.400 & 0.00 & 0.013 & 0.00 \\
\hline & Sunsrise & 3 & 46.1 & 4.04 & 22.7 & 2.69 & 2.30 & 2.52 & 2 & 0.460 & 0.11 & 0.015 & 0.00 \\
\hline & Abacus & 1 & 48.8 & & 19.4 & & 0.00 & & 1 & 0.460 & & 0.010 & \\
\hline & Aries & 3 & 44.2 & 9.19 & 22.7 & 3.61 & 6.00 & 4.24 & 1 & 0.390 & & 0.021 & \\
\hline & Comtess & 2 & 44.3 & 6.36 & 24.1 & 2.33 & 6.75 & 4.60 & 1 & 0.390 & & 0.021 & \\
\hline \multirow{2}{*}{ Fibre } & Belinka & 3 & 34.8 & 6.81 & 26.2 & 1.06 & 5.93 & 5.25 & 3 & 0.497 & 0.12 & 0.010 & 0.00 \\
\hline & Snaigiai & 1 & 42.2 & & 27.9 & & 11.00 & & & & & & \\
\hline \multicolumn{14}{|c|}{ F-test between varieties } \\
\hline F-value & & & $6.272^{* * *}$ & & $2.4855^{*}$ & & 1.28 & & & 1.66 & & 1.48 & \\
\hline $\mathrm{p}$-value & & & 0.0000 & & 0.0272 & & 0.2761 & & & 0.1492 & & 0.2045 & \\
\hline $\begin{array}{c}\text { df } \\
\text { effect }\end{array}$ & & & 10 & & 10 & & 10 & & & 9 & & 9 & \\
\hline df error & & & 40 & & 29 & & 39 & & & 27 & & 27 & \\
\hline
\end{tabular}


[7]. Linum seed oil contains 7-9\% palmitic, 4-6\% stearic, $18-$ 44\% oleic, 14-28 linoleic and 19-53\% alpha-linolenic acid [17-19]. High linoleic and low linolenic acid contents are found only in mutant genotypes of Linum usitatissimum [18]. Linoleic and linolenic acids are essential fatty acids for human beings, and gamma-linolenic acid is also an essential fatty acid [20]. Gamma-linolenic acid has many beneficial effects on health, e.g. decreasing the effects of atopic dermatitis [21]. Stearidonic acid has a role in synthesis of prostaglandins [7]. Hemp oil with exceptional and rare fatty acid composition is very beneficial oil for health of humans.

Oil of oil hemp contained high chlorophyll content (138 mg kg-1) (Table 2) compared to oilseed (0-6.75 mg kg-1) and fiber flax varieties (5.9-11.0 mg kg-1) Finland (Table 1). High chlorophyll content is caused by unripe green seeds containing chlorophyll. Chlorophyll content is an indication of maturity of seeds. It is important in areas where summer is short and cool. High chlorophyll content is not liked by food industry, because it colors the oil and limits the usage of oil in food industry. Food industry in Finland uses the value of 20-30 mg kg-1 for chlorophyll content of oil, the higher values cause decrease in price. Hemp oil cannot be used as food oil in normal food processes, but it has special uses as healthy product for its beneficial and exceptional fatty acid composition. In rapeseeds (Brassica napus L.) chlorophyll content is lower by early sowing, higher seeding rate and lower branching of the crop [22]. Chlorophyll can be precipitated and removed from edible oils e.g. by $2400 \mathrm{mg} \mathrm{L}^{-1}$ phosphoric acid at $120^{\circ} \mathrm{C}$ [23].

Table 2: Chemical composition from dry matter of seeds of oil hemp cultivated in south-western part of Finland in 2005, 2007-11.

\begin{tabular}{|c|c|c|c|c|c|c|}
\hline Cultivar & & $\begin{array}{c}\text { Oil } \\
\text { contents } \\
\left(\mathrm{g} 100 \mathrm{~g}^{-1}\right)\end{array}$ & $\begin{array}{c}\text { Protein } \\
\text { contents } \\
\left(\mathrm{g}^{100 \mathrm{~g}^{-1}}\right)\end{array}$ & $\begin{array}{l}\text { Chlorophyll } \\
\text { contents (mg } \\
\left.\mathrm{kg}^{-1}\right)\end{array}$ & $\begin{array}{l}\text { Cadmium } \\
\text { contents } \\
\left(\mathrm{mg} \mathrm{kg}^{-1}\right)\end{array}$ & $\begin{array}{c}\text { Lead } \\
\text { contents } \\
\left(\mathrm{mg} \mathrm{kg}^{-1}\right)\end{array}$ \\
\hline \multirow{3}{*}{ Finola } & Mean & 34.6 & 25.7 & 138.3 & 0.020 & 0.019 \\
\hline & Std. Dev. & 1.39 & 1.4 & 31.9 & & \\
\hline & $\begin{array}{l}\text { Number } \\
\text { of fields/ } \\
\text { samples }\end{array}$ & 6 & 6 & 4 & 2 & 2 \\
\hline
\end{tabular}

Oilseed and fiber flax cultivars differed significantly in protein contents. Protein contents were higher in fiber flax cultivars $\left(26.2-27.9 \mathrm{~g} 100 \mathrm{~g}^{-1}\right)$ than in oilseed flax cultivars (19.4-24.1 g $100 \mathrm{~g}^{-1}$ ) (Table 1). Protein content of oil hemp

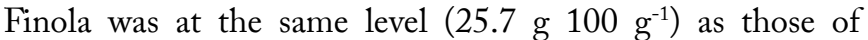
fiber flax cultivars (Table 2). Malhi et al. [24] have studied $\mathrm{N}$ uptake and protein content in 4 flax cultivars in 3 years in Saskatchewan in Canada. It seems that protein content is very much genotype dependent.

Cadmium contents were much lower in oil hemp cultivar Finola compared to oilseed and fiber flax cultivars (Table 1 and 2). Flax seeds accumulate cadmium. It was found that low $\mathrm{pH}$ of soil accumulates cadmium to flax seeds [14]. Cadmium contents of oil hemp were at the same level as found by Korkmaz et al. [25] in Western Turkey (5-23 $\left.\mu \mathrm{g} \mathrm{kg}{ }^{-1}\right)$. Many researchers have found that hemp is accumulating cadmium from the soil and hemp is thought to be a possible crop for phytoremediation in heavy metals polluted areas [13, 26-28].
Linger et al. [13] have found that the leaves accumulate more cadmium that seeds or fiber in hemp. Shi et al. [28] have found differences in cadmium accumulation capacity in hemp genotypes. Mihoc et al. [29] have studied cadmium contents of seeds of 5 oil hemp varieties in Romania and found high cadmium contents in them (means $1.9-3.4 \mathrm{mg} \mathrm{kg}^{-1}$ ), the values being higher than the cadmium contents found in flax and hemp samples in Finland (Table 1 and 2). Lead contents were low in flax and hemp samples (Table 1 and 2). According to the present results Finola hemp cultivar seems to be rather safe as food plant cultivated in Finland.

\section{Conclusions}

Oil, protein, chlorophyll, cadmium and lead contents were studied in seed yields of oil and fiber flax cultivars and in oil hemp cultivar Finola in south-western part of Finland. Chlorophyll content of hemp oil was high for the late maturity. Cadmium contents in oil and fiber flax were high, and in oil hemp Finola very low. Finola oil hemp seems to be safe as food plant as cultivated in Finland.

\section{Acknowledgements}

This research was financed by the Rural Development Programme for Mainland Finland of EU. We thank Satakunta and Pirkanmaa Centers of Economic Development, Transport and the Environment for their financial support and participating farmers and research units.

\section{References}

1. El-Alfy AT, Ivey K, Robinson K, Ahmed S, Radwan M, et al. 2010. Antidepressant-like effect of [Delta] 9-tetrahydrocannabinol and other cannabinoids isolated from Cannabis sativa L. Pharmacol Biochem Behav 95(4): 434-442. doi: 10.1016/j.pbb.2010.03.004

2. Gaoni Y, Mechoulam R.1964. Isolation, structure, and partial synthesis of an active constituent of hashish.J Amer Chem Soc 86(8): 1646-1647. doi: 10.1021/ja01062a046

3. Geller T. 2007. Cannabinoids: a secret history. Chemical Heritage Newsmagazine 25(2).

4. EUR-Lex, Access to European Union Law. 1998. Council Regulation (EC) No1420/98 amending Regulation (EEC) No 619/71 laying down general rules for granting aid for flax and hemp.

5. Bhatnagar A, Sain M. 2005. Processing of cellulose nanofiberreinforced composites. J Reinforced Plastics Compos 24(12): 1259-1268. doi: 10.1177/0731684405049864

6. Hana RS, Saed N. 2013. Alteration of oxidants, antioxidants and cytokines levels in blood of malathion exposed human and animal groups and the effect of flaxseed oil in alleviating malathion toxic effects. Eur J Biotechnol Biosci 1(1): 8-19.

7. Callaway JC, Tennilä T, Pate DW. 1996. Occurrence of "omega-3" stearidonic acid (cis- 6, 9, 12, 15-octadecatetraenoic acid) in hemp (Cannabis sativa L.) seed. J Intern Hemp Assoc 3(2): 61-63.

8. Callaway JC. 2004. Hempseed as a nutritional resource: An overview. Euphytica 140(1-2): 65-72. doi: 10.1007/s10681-004-4811-6

9. Kriese U, Schumann E, Weber WE, Beyer M, Matthäus BL. 2004. Oil content, tocopherol composition and fatty acid patterns of the seeds of 51 Cannabis sativa L. genotypes. Euphytica 137(3): 339-351. doi: 10.1023/B:EUPH.0000040473.23941.76

10. Schwab US, Callaway JC, Erkkilä AT, Gynther J, Uusitupa MIJ, et al. 2006. Effects of hemseed and flaxseed oils on the profile of serum 
lipids, serum total and lipoprotein lipid concentrations and haemostatic factors. Eur J Nutr 45(8): 470-477. doi: 10.1007/s00394-006-0621-Z

11. Dhiman TR, Satter LD, Pariza, MW, Galli MP, Albright K, et al. 2000. Conjugated linoleic acid (CLA) content of milk from cows offered diets rich in linoleic and linolenic acid. J Dairy Sci 83(5): 1016-1027. doi: 10.3168/jds.S0022-0302(00)74966-6

12. Li Y-M, Chaney RL, Schneiter AA, Miller JF, Elias EM, et al. 1997. Screening for low grain cadmium phenotypes in sunflower, durum wheat and flax. Euphytica 94(1): 23-30. doi: 10.1023/A:1002996405463

13. Linger P, Mussig J, Fischer H, Kobert J. 2002. Industrial hemp (Cannabis sativa L.) growing on heavy metal contaminated soil: fibre quality and phytoremediation potential. Industrial Crops Prod 16(1): 3342. doi: 10.1016/S0926-6690(02)00005-5

14. Saastamoinen M, Pihlava J-M, Eurola M, Klemola A, Jauhiainen L, et al. 2013. Yield, SDG lignan, cadmium, lead, oil and protein contents of linseed (Linum usitatissimum L.) cultivated in trials and at different farm conditions in south-western part of Finland. Agric Food Sci 22(2): 296-306.

15. MMM 1991. Agriculture and Forestry Ministry's decision on the condition and quality of the assay followed the instructions of grain. (in Finnish).

16. Bayrak A, Kiralan M, Ipek A, Arslan N, Cosge B, et al. 2010. Fatty acid composition of linseed (Linum usitatissimum L.) genotypes of different origin cultivated in Turkey. Biotechnol Biotechnol Equipment 24(2): 1836-1842. doi: 10.2478/V10133-010-0034-2

17. McGregor WG, Carson RB. 1961. Fatty acid composition of flax varieties. Can J Plant Sci 41(4): 814-817. doi: 10.4141/cjps61-120

18. Green AG. 1986. A mutant genotype of flax (Linum usitatissimum L.) containing very low levels of linolenic acid in its seed oil. Can J Plant Sci 66(3): 499-503. doi: 10.4141/cjps86-068

19. Popa V-M, Gruia A, Raba D-N, Dumbrava D, Moldovan C, et al. 2012. Fatty acid composition and oil characteristics of linseed (Linum Usitatissimum L.) from Romania. J Agroaliment Process Technol 18(2): 136-140.
20. Horribin DF. 1992. Nutritional and medical importance of gammalinolenic acid. Progress Lipid Res 31(2): 163-194. doi: 10.1016/01637827(92)90008-7

21. van Gool CJ, Thijs C, Henquet CJ, van Houwelingen AC, Dagnelie PC, et al. 2003. Gamma-Linolenic acid supplementation for prophylaxis of atopic dermatitis---a randomized controlled trial in infants at high familial risk. Am J Clin Nut 77(4): 943-951.

22. Ward KA, Scarth R, Daun J, McVetty PBE. 1992. Effects of genotype and environment on seed chlorophyll degradation during ripening in four cultivars of oilseed rape (Brassica napus). Can J Plant Sci 72(3): 643-649. doi: 10.4141/cjps92-080

23. Diosady LL. 2005. Chlorophyll removal from edible oils. Intern J Appl Sci Engineer 3(2): 81-88.

24. Malhi SS, Lemke R, Mooleki SP, Schoenau JJ, Brandt S, et al. 2008. Fertilizer $\mathrm{N}$ management and $\mathrm{P}$ placement effects on yield, seed protein content and $\mathrm{N}$ uptake of flax under varied conditions in Saskatchewan. Can J Plant Sci 88(1): 11-33. doi: 10.4141/CJPS07042

25. Korkmaz K, Kara SM, Ozkutlu F, Gul V. 2010. Monitoring of heavy metals and selected micronutrients in hempseeds from North-western Turkey. African J Agric Res 5(6): 463-467. doi: 10.5897/AJAR09.787

26. Linger P, Oswald A, Haensler J. 2005. Cannabis sativa L. growing on heavy metal contaminated soil: growth, cadmium uptake and photosynthesis. Biologia Plantarum 49(4): 567-576. doi: 10.1007/ s10535-005-0051-4

27. Shi G, Cai Q. 2009. Cadmium tolerance and accumulation in eight potential energy crops. Biotechnol Adv 27(5): 555-561. doi: 10.1016/j. biotechadv.2009.04.006

28. Shi G, Liu C, Cui M, Ma Y, Cai Q. 2012. Cadmium tolerance and bioaccumulation of 18 hemp accessions. Appl Biochem Biotechnol 168(1): 163-173. doi: 10.1007/s12010-011-9382-0

29. Mihoc M, Pop G, Alexa E, Radulov I. 2012. Nutritive quality of Romanian hemp varieties (Cannabis sativa L.) with special focus on oil and metal contents of seeds. Chem Central J6(1):122. doi:10.1186/1752153X-6-122 